\title{
A politização em condições politicistas: alguns problemas analíticos e resultados de trabalhos
}

Odaci Luiz Coradini'

\section{Resumo}

Neste artigo são examinadas algumas implicações do estudo da politização, com ênfase nas possibilidades e nos limites atinentes às condições periféricas. Para tanto, na primeira parte do texto são apresentados alguns elementos gerais relativos às definições propostas por Jacques Lagroye, sobretudo enfatizando as bases teóricas e os problemas epistemológicos subjacentes. A segunda parte da exposição utiliza resultados de investigações realizadas nas últimas décadas, em diferentes universos empíricos no Brasil e que abrangem direta ou indiretamente questões relativas à politização ou temas conexos. A partir delas são evidenciados problemas decorrentes, por um lado, das dificuldades ocasionadas pela falta de autonomia das Ciências Sociais, e, por outro lado, dos desafios ligados às particularidades sócio-históricas. Uma vez que, nesses contextos, é atribuído maior peso à "política" na estruturação social, bem como seus princípios de definição são diversos e múltiplos, além de haver múltiplos circuitos, com princípios de seleção distintos, que circunscrevem algo que pode ser tido como da ordem "política".

Palavras-chave: Politização. Lagroye. Periferia. Ciências sociais.

\section{Introdução}

Os objetivos deste texto diferem um tanto daquele formato de apresentaçáo de resultados de trabalhos centrados em algum problema específico, com a utilização da respectiva base de dados e metodologia própria. No presente caso, trata-se de apresentar uma síntese de alguns problemas e resultados de esforços no estudo de politizaçáo e temas conexos em condiçóes brasileiras. Portanto, além da oportunidade de um relato sintético, também pode servir como reflexáo sobre este tipo de problema.

I Professor de ciências sociais na Universidade Federal do Rio Grande do Sul (UFRGS). 
Em termos formais, o texto é constituído, basicamente, por duas partes. $\mathrm{Na}$ primeira, são apresentados alguns elementos gerais relativos às definiçóes propostas por Lagroye (2003b, 1991). Isso decorre do fato de que, no caso em pauta, estas conceituaçóes e respectivas bases teóricas e conceituais têm sido a principal fonte para a apropriação de esquemas analíticos concernentes à politizaçáo e temas conexos nos trabalhos sinteticamente comentados na segunda parte. Além disso, e que parece ser o mais importante, conforme uma das ideias gerais que orientam o texto, se por um lado conceitos como o de politização podem constituir ótimos instrumentos analíticos; por outro, representam um forte perigo de substancialização e sua transformação em algo a ser "aplicado" para a constatação de determinada "realidade". Esta substancialização pode ser reforçada pelo raciocínio analógico, inclusive porque se trata de um conceito que abrange processos e, consequentemente, sua utilização pode se tornar muito propensa à redundância, ou seja, a formulação de determinado problema de investigação (a "politizaçâo") cuja resposta está contida na sua própria formulação. É tendo isso e outros problemas desta ordem em vista que são apresentados ou destacados alguns dos elementos da fundamentação epistemológica e teórica da conceituação de politização em pauta e dos desafios (ou impasses) representados pelas condiçóes periféricas.

\section{A politização como conceito e como inscrição em perspectivas teóricas e epistemológicas}

Como é sabido, nas ciências sociais, com exceção de poucos casos em que algum conceito é formulado através de algum neologismo, em geral a formulação ocorre pela redefinição de termos de uso comum, como é o caso daquele de politização. Isso implica, em primeiro lugar, que os princípios dessa redefinição remetem às respectivas bases teóricas, que passam a estar presentes na própria definição conceitual. Em segundo lugar, no que tange especificamente ao conceito de politização, sua definição implica a conversão, ou seja, um processo de transformação de algo supostamente externo passando a ser referido como da ordem da "política" ou daquilo que foi "politizado". Assim, está presente na própria definição conceitual de politização o problema mais geral do que seja a própria "política", em oposição àquilo que seria externo à mesma. Por mais elementares que possam parecer estas ideias gerais, é necessário tê-las presente ao apreender as diferentes perspectivas conceituais e metodológicas no estudo da politização. 
Embora possa parecer elementar, também é necessário destacar que tanto a conceituação como os estudos relativos à politização e a temas conexos abrange o conjunto das ciências sociais no ocidente, não se restringindo, portanto, à França. Porém, mesmo deixando de lado as ciências sociais anglo-saxônicas e tomando apenas a França, este tipo de estudo vai muito além dos trabalhos de Lagroye ou de seus seguidores. Nesse sentido, uma das principais e mais antigas linhas de investigação de politização consiste naquela que tem como principal eixo temas relativos à constituiçáo do corpo eleitoral ou a expansão dos processos eleitorais e a gradativa incorporação da população até então excluída da "política" - dentre outros, ver particularmente Garrigou (1992); Gaxie (1978); Offerlé, (2007); Lacroix (1985). Porém, como já foi mencionado, a orientação teórica e a linha de trabalho de Lagroye mantém uma posição relativamente própria. Para uma melhor compreensão de suas potencialidades, limites e desafios, é necessário destacar alguns pontos, especialmente nos esforços em sua utilização no estudo em condiçôes periféricas. Alguns desses pontos têm sido destacados ou pelo menos apontados nas exegeses realizadas nos últimos anos. Por outro lado, outros aspectos tidos como centrais não chegam a ser apontados nessas exegeses, talvez como efeito da dinâmica do próprio espaço das ciências sociais na França.

O primeiro desses aspectos centrais que tem efeitos decisivos nas condições de apropriação e utilização da definição de politização de Lagroye consiste na concepção de "política" e suas implicações em definiçôes correlatas, tais como a de "poder". Apesar da forte influência das abordagens interacionistas no que tange a outros pontos, como os vinculados às lutas e competiçóes no espaço político (LAGROYE, 1973) ou nas relaçôes e usos das regras institucionais e, inclusive, para se contrapor às perspectivas institucionalistas, tomando como objeto as próprias definiçóes daquilo que seriam as instituiçóes (LAGROYE; OFFERLE, 2010), as definiçôes de "política" remetem diretamente à sociologia da dominação de Weber (LAGROYE, FRANÇOIS; SAWICKI, 2002, p. 36-38). Sinteticamente, em primeiro lugar, é daquilo que não dispóe de alguma "soluçáo" de outra ordem e, consequentemente, torna-se um problema "político" (no sentido da "continuação da guerra por outros meios"). Em segundo lugar, trata-se do poder de "arbitragem" (ou de "governo"), em oposição àquele de mediação e influência. Em terceiro lugar, trata-se também de algo que necessariamente se constitui em um princípio de diferenciação 
social, a começar pela divisão entre os que "governam" e os "governados", o que necessita de meios de legitimação próprios (LAGROYE, 1985). Por fim, em quarto lugar, sem qualquer pretensão de exaustão, nessa perspectiva a dominação política não constitui algum "setor" ou alguma "coisa”, mas determinada dimensão da estrutura social. Porém, novamente calcado diretamente em Weber (1984), esta dimensão específica difere das demais por não fazer parte da divisão social do trabalho. Esses pressupostos já vinham sendo enunciados muito antes do texto dirigido diretamente à conceituaçáo da "politização", particularmente no manual de sociologia política, cuja primeira edição é de 1991. Entretanto, todas estas ideias estão diretamente na base da definição de politização como “[...] requalificação das atividades sociais as mais diversas, que resulta de um acordo prático entre agentes sociais inclinados por múltiplas razóes, a transgredir ou a pôr em questão a diferenciação dos espaços de atividades" (LAGROYE, 2003b, p. 360-361). Mas, além das relaçóes diretas dessas premissas fortemente calcadas na sociologia da dominação de Weber, como é destacado adiante, esta definição de "política" como aquilo que não dispóe de alguma "soluçáo" opóe-se frontalmente a outras perspectivas com forte expansão e uso tanto na definição de "política" como de "politização". Trata-se, em especial, de perspectivas com base em filosofias políticas e em bases teóricas das ciências sociais, como as associadas ao contratualismo ou ao chamado "pluralismo", seja em sua versão mais liberal ou mais calcada na moral da "comunidade cívica”, em síntese, cuja base epistemológica está assentada em alguma moral cívica. Ocorre que, independentemente da versão da moral cívica em pauta, a "política” passa a ser definida como problema de "gestão" e de poder de influência (BRAUD, 1985), como é mais bem detalhado adiante. Em todo caso, em condições periféricas como aquelas em pauta, onde as próprias ciências sociais tendem a ser normativamente concebidas como auxiliares ou instrumentais a esta "gestão" e à moral cívica subjacente, a questão mais imediata consiste na própria razão de ser de posiçóes teóricas e conceituais como aquelas de Lagroye.

Estas premissas subjacentes de "política" e de "politização", dentre outras, de Lagroye estão inscritas em uma concepção da "política” moderna como espaço ou esfera de atividades com autonomia relativa muito frágil ou com forte heteronomia, como é muito destacado, inclusive, por exegetas (AÏT-AOUDIA et al., 2010, p. 213). Isso abrange aquelas situaçóes que, por definição, 
comportariam um maior grau de autonomia das atividades ou da dimensão política, como as democracias ocidentais. Mesmo nessas condições, a dominação política é diretamente interdependente das demais esferas de atividade e formas de dominação, o que tem implicaçóes na definição e nos esquemas de análise da politização.

Ocorre que, como já mencionado, a politização equivale a uma conversão de algo (questóes, agentes) que passa a ser referido como sendo relativo à "política". Isso, evidentemente, possibilita uma grande amplitude daquilo que, em princípio, pode passar a constituir objeto de politização. Certamente, é decorrente disso o fato de que um dos aspectos mais destacados na definição de politização (LAGROYE, 2003b) consiste na diversidade de possibilidades concretas desse tipo de processo.

Esta diversidade nos processos de politização está associada à polissemia (LASCOUMES, 2009, p. 458) nos usos do conceito, o que tem suscitado algumas discussões nas ciências sociais na França. Algumas dessas discussóes parecem muito pertinentes; porém, outras são completamente discutíveis. Dentre estas discussóes cujas próprias bases são questionáveis, destacam-se aquelas que visam a um maior grau de especificação do conceito, o que implica maiores restriçóes em sua amplitude e usos. Sem pretensão de negar o problema da amplitude das definiçôes e usos do conceito, contudo, algumas dessas críticas apontam no sentido de uma concepção subjacente de ciências sociais como uma espécie de exercício de "aplicação de conceitos". Assim, mais do que o problema da amplitude ou da diversidade dos usos da definição de politização, entra em pauta a busca de alguma definiçáo com pretensóes de "desvendar" determinada "realidade". Outro ponto negativo nessas discussôes, sobre o qual também não caberia entrar em maiores detalhes, consiste na utilização normativa dos estudos de politização, no sentido de ressaltar determinado processo como algo positivo por ser convergente com a moral cívica vigente - ver, por exemplo, Talpin (2010) -, com destaque a aspectos como "participação", "cidadania" e assim por diante. O mesmo se aplica à politização tomada normativamente como algo negativo, que geralmente está associado a alguma estratégia de desqualificação.

Em todo caso, para além desse tipo de discussáo, o problema da diversidade dos processos de politização nesta perspectiva de Lagroye persiste. Nesse 
sentido, seria questionável, inclusive a validade ou os resultados desses esforços no sentido da especificação do conceito, cujas justificativas e objetivos podem ser metodologicamente criticáveis, inclusive a ideia geral da divisão entre definiçóes "amplas" e "restritas" de politização. Isso decorre do fato de que tanto os processos de politização como aquilo que pode ser considerado como política não consiste em alguma "realidade" empírica substantiva ou algo setorialmente recortável enquanto tal, mas de uma dimensão da estrutura e da dinâmica social, como destacado especificamente por Lagroye (1991, p. 22-26). Por outro lado, recentemente têm surgido também proposiçóes que podem contribuir para a explicitação de aspectos do conceito. Este é o caso, particularmente, de algumas contribuiçóes de Lascoumes, dentre outros (LASCOUMES, 2009; AÏT-AOUDIA et al., 2011; HAMIDI, 2006; DUCHESNE; HAEGEL, 2004). No que tange a Lascoumes (2009), incorporando inclusive outras bibliografias predominantemente de origem norte-americana no estudo dos processos de politização, de despolitizaçáo e de repolitização na dinâmica parlamentar, é proposto um esquema que inclui a superpolitização e a subpolitização em diferentes modalidades. É pressuposto que a análise desses processos poderia contribuir para especificar as relaçóes entre as politics e as policies, bem como as diferentes formas de politização, como a ideológica, a institucional, a militante e de despolitização, como a ideológica, a procedimental e a técnica (LASCOUMES, 2009). De uma perspectiva distinta, Duchesne e Haegel (2004) propóem um esquema básico centrado nas relaçóes entre especialização política e conflituosidade e, ao que tudo indica, não por acaso, um recorte empírico centrado no estudo dos discursos ideológicos em disputa nas políticas governamentais. Essas diferenças analíticas, como é retomado adiante, parecem muito sintomáticas quanto a algumas questóes de fundo desse tipo de estudo. Em uma linha próxima, para mencionar mais um exemplo nessas diferenças de abordagens, Hamidi (2006), também tendo por base noções como especialização política e conflitualização, toma como recorte empírico associações de imigrantes e mais especificamente, as relaçóes entre engajamento associativo e a política definida como institucionalizada e os processos de politização.

Por sua vez, o trabalho de Aït-Aoudia et al. (2011) - ver também Aït-Aoudia et al. (2010) - torna alguns dos problemas nesse tipo de estudo mais explícitos em um esforço no sentido da busca de maiores especificações 
do conceito e dos "indicadores", por um lado, fica evidente o já mencionado problema de ciências sociais como "aplicação de conceitos" e, portanto, da necessidade de sua especificaçáo. Nessa perspectiva, o conjunto de trabalhos editados por Lagroye (2003a) conteria "[...] quase uma dezena de acepçóes diferentes do conceito de "politização" e, consequentemente, não se poderia saber se seriam "os mesmos fenômenos que são analisados e discutidos" (AÏT-AOUDIA et al., 2011, p. 10). Por outro lado, são apresentados resultados do esforço coletivo para definir a "politização dos indivíduos" e a "concepção estrita” das abordagens das relaçôes com a "esfera institucional”. Independentemente da falta de especificação e das ambivalências da conceituação de Lagroye (2003b), certamente em decorrência dos vínculos dos autores com o estudo de sociedades muçulmanas, são formuladas algumas questôes muito pertinentes. A principal destas questôes consiste na restrição da conceituação de Lagroye (2003b) "essencialmente em uma perspectiva democrática”, do que decorreria sua abordagem restritiva e a necessidade de uma concepção ampla de politização (AÏT-AOUDIA, 2011, p. 13). Isso implicaria a necessidade da abordagem da política para além da esfera institucional e, mais especificamente, o que é designado como vetores da politização. Trata-se de "empresários" da politização e sua diversidade. Cabe notar que são estes mesmos autores que em um comentário anterior sobre a "concepção lagroyana de politização", destacam especialmente as afinidades desta abordagem para o estudo de condiçóes como aquelas do Oriente Médio e da África do Norte. Em suas palavras, a "[...] questão da 'construção social da política' é essencial no estudo das sociedades democráticas, mas adquire uma importância ainda maior quando se dirige para outros tipos de regime" (AÏT-AOUDIA, 2011, p. 13). Nesse sentido, a vantagem da concepção lagroyana de politização "[...] está precisamente no fato de que ela convida a superar as abordagens focalizadas nos fluxos da cena eleitoral. Em contrapartida, estes terrenos ditos exóticos podem constituir analisadores privilegiados de processos de produção social da política" (AÏT-AOUDIA, 2011, p. 13). Este esquema de Lagroye, portanto, seria particularmente fecundo no estudo de política comparada, em especial em três eixos: "a politização de atores, grupos e questôes; aquela de atividades e de práticas; os processos de politização e de repolitização", além da "entrada" na política de categorias como militares, mulheres, empresários, dentre outros (AÏT-AOUDIA et al., 2010, p. 215-217). 
Independentemente do grau de aceitação ou não das posiçôes assumidas nesses comentários, é necessário reconhecer que, direta ou indiretamente, estâo presentes alguns dos problemas mais gerais nessa abordagem de Lagroye da politização. Um dos principais desses problemas, que nem chega a ser mencionado nestes comentários sinteticamente citados, consiste na própria amplitude da definição de política. Desde a primeira edição de Sociologie Politique (LAGROYE, 1991), o primeiro capítulo, tematicamente sobre a "especialização dos papéis políticos", tem como problema central as possibilidades e os limites da formulação de um conceito universal de "política". Como é sabido, esta possibilidade somente se mostra viável em um nível extremamente geral, sendo o denominador mínimo da "política" o "governo", no sentido da arbitragem pela coerção e não mais subordinada às relaçôes de mediação.

Ocorre que, por mais que a concepçáo de política de Lagroye enfatize seu caráter de algo socialmente constituído, a definição de politização está referida à política moderna ocidental, portanto, concebida como "representação" política. Não vêm ao caso as questôes em aberto quanto às condiçôes e aos graus em que os processos eleitorais possam definir ou influenciar as agendas de políticas governamentais. O que deve ser destacado é que, mesmo na hipótese de que os efeitos da representação política sejam mínimos nas estruturas das decisôes políticas, está sempre presente como referencial para a formulação e, particularmente, para a legitimação de decisóes políticas. Logo, nessas condiçôes específicas das democracias ocidentais há modalidades próprias nas relaçôes entre as formulaçóes, as decisôes e a legitimação da política. A principal consequência metodológica disso para as ciências sociais é a de que se trata de condiçôes próprias e específicas nas relaçôes entre práticas sociais e políticas e nos discursos e categorizaçóes e publicidade da "política".

Frente a este tipo de problema, a principal alternativa posta em prática por pesquisadores de sociedade extraocidentais, a qual inclui os autores supracitados, tem sido a ênfase na diversidade das modalidades de processo de politização e, particularmente, de expressão de categorias sociais que podem ser consideradas como "políticas". Isso, evidentemente, é indispensável. Porém, para além da diversidade do que pode constituir a "política" em condiçôes nas quais não é concebida e posta em prática como representação, há outro problema geral em aberto. $\mathrm{Na}$ ausência da "representaçáo" como referencial para a 
constituição e legitimação da "política" ou, então, de sua presença como simulacro nas sociedades não ocidentais, as condiçóes de formação e de expressão discursiva e, portanto, as categorias e os princípios de legitimação do que seja a "política" decorrem de outras lógicas de ação e têm outros significados. Se, por um lado, como destacado por Badie e Hermet (1993, p. 189-195), nas sociedades periféricas a "política" mantém um peso maior na conformação da estrutura de posições e acesso a recursos sociais; por outro lado, não há algum referencial universalizável para os significados do que constitui esta "política”. Isso não decorre apenas do menor peso dos processos eleitorais, mas da inexistência de um corpo eleitoral e de uma agenda "política" que sirvam de referencial geral. Isso não implica menor intensidade dos confrontos de interesses e de ideologias "políticas", mas seu caráter restrito e ambivalente, visto que normalmente não dirigido e legitimado frente a algum público geral, mas em esferas ou circuitos específicos e restritos. É o caso, para citar os exemplos mais evidentes, do clientelismo, das diferentes modalidades de corporativismo e de neopatrimonialismo, de diferentes modalidades de "lobbismo", do spoil system, dentre tantas outras modalidades de realização de interesses na "política”. Seja como for, importa destacar que, nessas condiçóes, se por um lado o peso de algo que pode ser referido à "política" é maior; por outro, as lógicas de ação e os significados presentes na geração e legitimação de categorias "políticas" são menos evidentes e, em geral, tornadas públicas apenas de modo restrito e controlado. Disso resulta, inclusive, o caráter ambivalente das referências e categorias que remetem à "política” e, também, de um fenômeno típico deste tipo de sociedade periférica que consiste na tendência de os interesses organizados com maior eficácia na ação política em termos de influência nas decisóes serem aqueles com menor ação no sentido da legitimação pública geral.

Metodologicamente, uma das principais consequências disso consiste na necessidade de contemplar nas pesquisas tanto as categorias que aparecem como explicitamente referidas à "política" quanto as condições de sua enunciação e legitimação e os universos sociais que as respaldam. Além disso, passa a ser decisiva a inclusão daqueles interesses e categorias não necessários e diretamente referidos à "política", mas cuja realização de interesses, direta ou indiretamente, passa por instâncias "políticas”. Sinteticamente, é o problema mais geral das relaçóes entre o objetivismo e o perspectivismo e da necessidade de contemplar ambos. Ocorre que o objetivismo pode aparecer nas ciências 
sociais como projeção de uma concepção ingênua que pressupõe uma "realidade objetiva" dada a ser desvendada mediante a "aplicação" de determinados conceitos. Todavia, também pode ter o significado de uma perspectiva que pressupóe a necessidade de incluir na investigação mais do que aquilo que tem condiçóes de emergir discursivamente, seja porque não há interesse em sua apresentação pública ou, inclusive, porque a condição de eficácia depende de sua dissimulação, além daquilo que pode remeter a algo da ordem do impensado. Obviamente, isso deve incluir as perspectivas e os discursos explícitos, embora seu mero registro e a ênfase em sua diversidade não sejam suficientes.

No que tange especificamente à bibliografia supracitada, há uma postura contrária à inclusão na pesquisa daquilo que não está explicitamente presente nos discursos, sob o argumento de se tratar de "objetivismo". Nesse sentido, boa parte dos participantes da coletânea dirigida por Lagroye (2003) é classificada como tal, como exemplo principal sendo tomado o trabalho de Eymeri (2003 apud AÏT-AOUDIA et al., 2010, p. 212). Porém, de modo mais geral, este tipo de problema aparece na bibliografia dirigida a estudos de politização através de sua divisão conforme as respectivas orientaçóes teóricas e os recortes empíricos. Ocorre uma nítida tendência de aqueles com mais proximidade com abordagens perspectivistas se declararem adeptos de orientaçóes próximas do interacionismo ou algo semelhante, ao mesmo tempo em que centrados em recortes empíricos tomando algum "movimento" ou algo que é definido como externo à "política institucionalizada". Muitos destes trabalhos mantêm uma evidente associação com concepçóes normativas. No polo oposto, situam-se aqueles com pretensôes de incluir na análise da politização algo que abrange as perspectivas dos envolvidos nas práticas sociais, mas também as condições de sua emergência e de legitimação.

Em todo caso, embora não se possa tomar como alguma alternativa definitiva, frente a este tipo de problema se tornam ainda mais importantes indicaçôes como as de Lascoumes (2009) no sentido de considerar as relaçóes entre as politics, as policies, e as polity no estudo de processos de politização. Também adquirem maior importância indicaçóes como aquelas de Eymeri (2003), incorporando tanto as dimensóes objetivistas como perspectivistas. Também passa a ser importante a participação dos aparelhos de Estado ou das policies na politização e na formulação de políticas governamentais nos 
países centrais, que, no caso da França, também é enfatizada por diferentes trabalhos, dentre os quais aquele de Birnbaum (1994), com destaque para a posição central das "elites" do próprio setor público. De outra perspectiva, com destaque para o corporativismo estatal e sua associação com as políticas setoriais, algo semelhante é demonstrado por Jobert e Muller (1987). Por outro lado, isso pode ser reforçado pela tendência já constatada por Desrosières (2008) no sentido do "governo por instrumentos", o que é retomado por Lascoumes (2009) como um dos principais meios atuais de politizaçáo. No que tange especificamente às sociedades periféricas do tipo da América Latina isso se torna ainda mais decisivo ao se incorporar simultaneamente indicaçóes como aquelas de Badie (1994) e Badie e Hermet (1993, p. 189195) quanto ao peso e significado da "política" na estruturação social, e de Touraine (1988) e Hirschman (1963) relativas ao "poder" mais diretamente centrado na "participação", em detrimento da "representação".

Por fim, é necessário destacar outro ponto central dos esquemas analíticos em geral utilizados e, particularmente, naquele de Lagroye (2003b): as relaçóes dos processos de politização e da própria definição de política com as estruturas de representação, em especial através de processos eleitorais. Evidentemente, isso não significa que a representação política eleitoral não constitua um meio de politização, mas que a própria concepção de política tende a estar associada, de algum modo, a esta representação política. Desse modo, seja como recurso de legitimação de regime, de elites, de políticas ou de algo mais, mesmo quando a politização ocorre através de aparelhos de Estado ou de políticas governamentais, não deixa de ter como referência esta concepção de política com base na representação. Como indicado no próximo item, isso pode ter implicações decisivas nas condições de análise da politização, em contraste com as estruturas periféricas, a começar pelas próprias concepçóes e definiçóes de "política", além do problema central das condiçōes de estruturação de algum espaço de seu exercício e expressão pública.

\section{Politização, militantismo e representação de interesses}

Como já foi mencionado, neste item são apontados alguns problemas e desafios na utilização de conceitos como o de politização, especialmente na perspectiva teórica de Lagroye, em condiçóes periféricas como as brasileiras, 
com base em algumas experiências com esta linha de trabalho. Como é mencionado inclusive por alguns dos trabalhos de Lagroye, tanto os conceitos de politização como o conjunto de suas formulaçóes estáo diretamente associados a uma orientação teórica e epistemológica não redutível ao seu trabalho individual. Dito de outro modo, constitui-se uma linha de investigação e análise em ciências sociais que apesar das diferenças temáticas e metodológicas, mantém uma base comum. Faz parte desta base comum, em primeiro lugar, uma concepção de ciências sociais cuja existência requer determinado grau de autonomia frente às filosofias e lutas político-ideológicas. Além disso, como já mencionado, subjacentemente está presente uma concepção de política como poder de "arbitragem" através da coerção de conflitos sem possibilidades de outra solução, com base em determinado modo de dominação (LAGROYE, FRANÇOIS; SAWICKI, 2002, p. 36-37; LAGROYE, 1991). Portanto, é uma concepção independente das filosofias e da moral cívica que visam a alguma justificativa da existência de determinada forma de "política". Sem qualquer pretensão de exaustão, para o que é apontado a seguir, é necessário destacar que se trata de uma concepção da política moderna ocidental que pressupóe um baixo grau de autonomia relativa e, portanto, forte grau de heteronomia.

Evidentemente, nada disso pode ser encontrado em situaçóes como a brasileira, mas o mais importante a destacar por ora são as condiçóes de importação de modelos de ciências sociais. Como é sabido, nas condições periféricas em pauta, nunca houve qualquer emergência de algo significativo no sentido de alguma concepção ou de práticas das ciências sociais com um mínimo de autonomia. No entanto, com as novas condiçóes de importação de teorias, especialmente no que tange às disciplinas mais diretamente associadas com temas conexos à politização, essas condiçôes passaram por fortes alteraçôes. Isso ocorreu, em especial, naquilo que é designado como ciência política nos Estados Unidos e nos critérios de seleção em sua importação e adaptação na periferia.

Mesmo sem entrar em detalhes, é necessário destacar que nos Estados Unidos os modelos de análise de algum modo com base naquilo que genericamente é designado como "pluralismo" ocupam uma posição central, com diferentes versôes. Para o que está em pauta, importa destacar que, mesmo 
não entrando nas especificidades dessas diferentes versôes do "pluralismo", todas compartilham determinadas filosofias políticas estreitamente associadas com condiçôes históricas, sociais e culturais das respectivas formaçóes nacionais, dentre as quais, particularmente as dos Estados Unidos. Disso resulta uma concepção específica de sociedade, de poder e de política, tendo como base a oposição de algo como "sociedade civil" e categorias correlatas, representando a "não política", que equivaleria ao polo positivo. Disso decorre um esquema de entendimento e avaliaçáo que valoriza as relaçóes com base no poder de influência ou nas interaçóes e respectivos valores, como a "confiança", em oposição ao poder "político", concebido negativamente (BRAUD, 1985). Como um exemplo extremo dessa concepção e sua utilização na formulação de esquemas de análise nas ciências sociais e sua longa continuidade histórica, pode ser tomado o modelo proposto por Almond (1958) e seguidores para o estudo de grupos de interesse. Significativamente, dos quatro "modelos" descritos com base na comparação entre diferentes países, apenas o designado como "anglo-saxão" é apresentado positivamente, tendo em vista o caráter de "barganha" e concorrência, portanto "não político", das relaçóes de poder. A "política” é relegada como exclusividade dos partidos e esferas de decisão governamental. Em síntese, nesse esquema o polo representado pela "sociedade civil" equivale às relaçôes com base no mercado, na barganha e na "confiança" ou, mais recentemente, no capital social, em oposição à "política". No que tange às ciências sociais, a própria concepção de poder é radicalmente diversa daquelas com base na concepção weberiana, tendo como fundamento a instrumentalização de sua "gestão", em nome de princípios da moral cívica. As ciências sociais, evidentemente, estâo incluídas nesta instrumentalização.

Ainda quanto a esta concepção de política e de ciências sociais que pode ser sintetizada no "pluralismo" norte-americano, evidentemente, isso não abrange o conjunto das correntes e respectivas bases teóricas e epistemológicas, apesar da forte expansão recente em diferentes versôes. No que tange especificamente à sua submissão à agenda política governamental, como representante de uma posição contrária pode ser tomada como exemplar a crítica apresentada por Lowi (1992). Ou como descrito pelo próprio Almond (1988b, 1990), ainda quanto à ciência política nos Estados Unidos, mais que algum monopólio, a tendência principal seria a fragmentação em cinco segmentos ou grupos separados entre si, ou na metáfora utilizada, em "mesas 
separadas". Este confronto tem envolvido diretamente também algumas categorias centrais das ciências sociais, para além daquelas de "política" e de poder, como a de Estado. Novamente, nesse ponto também têm se destacado os confrontos entre Lowi (1988) e Almond (1988).

Estas condiçôes gerais sinteticamente apontadas nas fontes de importação de teorias de ciências sociais devem ser consideradas ao abordar as eventuais condiçốes e limites ou os impasses no estudo de processos de politização em condiçóes periféricas. Isso porque, se por um lado este tipo de esforço envolve condiçóes sociais e históricas muito particulares frente àquelas em que os esquemas analíticos foram formulados; por outro, também incluem as modalidades e os significados das importaçóes e usos destes esquemas.

Como já foi mencionado, conjuntamente com a expansão das teorias conexas ao "pluralismo" nos Estados Unidos, também tende a ocorrer uma crescente segmentação da ciência política, em uma espécie de "tribalização". Esta segmentação está inserida em um conjunto de confrontos entre posiçôes neste espaço que inclui o conjunto das ciências sociais (WACQUANT; CALHOUN, 1989). No que tange às sociedades periféricas, evidentemente, não se trata de alguma dinâmica no espaço das ciências sociais, nem de alguma transposição daqueles confrontos, mas das condiçóes de importação e apropriação de alguns de seus esquemas ou produtos. No entanto, estas condiçôes de importação e adaptação das ciências sociais devem ser consideradas conjuntamente com o politicismo característicos de sociedade periféricas e dos interesses e das perspectivas de apropriação e adaptação de esquemas importados.

Em seu trabalho sobre a importaçáo de esquemas de entendimento da economia e do direito dos centros internacionais, particularmente dos Estados Unidos para a América Latina, Dezalay e Garth (2002) defendem a hipótese conforme a qual a eficácia desse tipo de importação depende da existência de "equivalentes estruturais" entre as fontes e o destino desta importação. Todavia, tudo indica que, mais do que equivalentes estruturais entre interesses e posiçôes ideológicas entre os centros internacionais ocidentais e a periferia, além da assimetria das relaçóes centro/periferia, o que entra em pauta são as possibilidades de apropriação, retradução e usos de modelos culturais e políticos importados conforme as predisposiçóes e demandas preexistentes na 
periferia. No caso do direito e da economia estudados por Dezalay e Garth (2002), não está em pauta a importação de algo no sentido da moral puritana e nem de ideologias associadas ao homo economicus ou, ainda, do contratualismo subjacente à elaboração e universalização desse tipo de teoria social. O que de fato é importado e apropriado são determinadas derivaçôes na forma de versốes desses universais, seja o direito empresarial, a economia neoclássica e a defesa do mercado, ou outra matriz qualquer, mas sempre da perspectiva das demandas ou daquilo que Badie e Hermet (1993, p. 182-186) definem como estratégias de importaçáo preexistentes na periferia. Por isso, mais que o moralismo puritano característico sujamente às teorias sociais e particularmente ao "pluralismo" ou sua fusão com a agenda das políticas governamentais, é necessário ter em consideração as especificidades dos interesses e das concepçóes e expectativas periféricas relativamente às ciências sociais.

Se isso for verdadeiro, pode contribuir para a compreensão da dinâmica e dos resultados da importação de esquemas das ciências sociais, particularmente no que tange às possibilidades ou aos limites do estudo de processos de politização em condiçôes periféricas. Porém, além do moralismo subjacente às origens dos esquemas importados, tais como aqueles que fundamentam o "pluralismo" e conexos, no que tange aos importadores na periferia, deve ser considerado o politicismo que caracteriza tanto a estrutura de poder como as ideologias vigentes. Em termos gerais, o maior peso da "política", em oposição à economia, na estrutura social e de poder nas sociedades periféricas vem sendo destacado particularmente por Badie (1994), Badie e Hermet (1993) e, especificamente para a América Latina, Touraine (1988). Porém, para além da estrutura social e de poder, este peso da "política" se impóe também como princípio de entendimento no conjunto das ideologias e mitologias e, particularmente, nas ciências sociais, como já destacado por diferentes estudos, evidentemente, todos com autoria de estrangeiros (SAINT MARTIN, 1988; PÉCAUT, 1990). O mais intrigante é que, se a tese básica do trabalho de Pécaut (1990), em especial no que tange ao "realismo" da concepção de "política" dos "intelectuais" brasileiros for aceita, estudos como aqueles tendo como objeto processos de politização simplesmente não fazem sentido. Ou seja, a "política" consiste em algo dado e, por definição, em geral é algo positivo.

Por outro lado, para além do peso da "política" na configuração da estrutura social e de poder nestas condições periféricas, em oposição ao moralismo 
e às ideologias centradas no mercado nos Estados Unidos, é necessário considerar também as condiçôes concretas deste politicismo. Como já mencionado, não se trata apenas de um princípio estruturante dos recursos e posiçóes sociais, ao ponto de inverter o princípio marxista do capital econômico como recurso principal (BADIE; HERMET, 1993, p. 189-195), nem do peso das concepçôes politicistas que abrange inclusive as ciências sociais, mas também do militantismo e daquilo que Touraine (1988) designa como "participaçáa”, em oposição à "representação". Em termos práticos, tudo isso se realiza nas diferentes formas de "participação" interdependentes, dentre as quais, o corporativismo e o spoil system que interagem na representação de interesses.

Embora se trate de algo bem mais complexo e multifacetado, estes meios de representação e realização de interesses não podem ser detalhados aqui, mas para o que está em pauta importa destacar que têm efeitos, de modo diferenciado, no conjunto das ciências sociais. Isso deve ser considerado para a compreensão do fato de que, do conjunto de posiçóes na ciência política norte-americana descritas por Almond (1988b), objeto da crítica de Lowi (1992), foi justamente aquela com uma concepção mais instrumental e, portanto, a serviço das políticas governamentais que passou a se impor no Brasil.

Isso que à primeira vista pode parecer representar grandes guinadas nas orientaçóes teóricas com posiçóes dominantes, com destaque para aquelas com concepçóes mais instrumentais das ciências sociais, pode ser atribuído a um evidente efeito periferia. Sinteticamente, trata-se do fato de que, diversamente da fonte de importação, os Estados Unidos, onde ocorre um longo processo de confrontos entre diferentes perspectivas teóricas e epistemológicas, com alguns polos mais diretamente posicionados pela independência das ciências sociais em detrimento de outros mais próximos de concepçôes "gestionárias" e de "engenharia institucional" ou aplicação "prática" em geral; contudo, envolvendo os próprios fundamentos e princípios gerais, nas condiçóes brasileiras estes confrontos nem chegam a existir de modo significativo. Isso porque nas condiçôes prévias nunca houve algo significativo, em termos de concepçóes de ciências sociais, pressupondo sua autonomia como condição necessária. Assim, o predomínio de uma posição favorável a uma concepção de ciências sociais "gestionária" e "prática" não decorre de alguma dinâmica nos confrontos entre fundamentos epistemológicos, mas da "adoção" de determinada posição nos processos de importação, conforme os interesses e as predisposições 
preexistentes. Porém, como típico efeito periferia, isso cria as condições de difusão e imposição de uma interpretação conforme a qual a concepção de ciências sociais e, particularmente, da chamada ciência política, estritamente instrumental e "gestionária" decorreria de algum processo de confrontos entre posiçôes teóricas e epistemológicas (e nas versões mais abusadas, de um "campo”), que nunca existiram nem como mera questáo.

Seja como for, para o que está em pauta, importa destacar as implicaçóes disso para as possibilidades e os limites no que tange a estudos de processos de politização e seus limites. Evidentemente, para esta concepção instrumentalista e de aplicação "prática” das ciências sociais que, no limite, se posiciona inclusive explicitamente em âmbito externo às mesmas, chegando a uma situação próxima de uma espécie de administração pública de outra categoria, os problemas analíticos envolvidos nos estudos de processo de politização e temas conexos, na perspectiva em pauta, náo fazem qualquer sentido. Quanto aos segmentos menos diretamente instrumentalizados, em âmbito local e nativo, até onde vão as informações, também não parece haver condições férteis. Nesse caso isso decorre menos da pretensão de fusão da agenda das ciências sociais àquela das políticas governamentais e, particularmente, devido ao fato de que nesse caso ocorre uma maior associação com alguma versão da moral cívica vigente, tomada inclusive como pressuposto. Dentre outras implicaçóes, isso resulta na já mencionada concepção de poder no sentido "gestionário" e sua associação com a moral cívica. Novamente, seja como for, com este tipo de concepção de poder e de ciências sociais, seria muito difícil imaginar alguma preocupação ou prática de estudo de politização no sentido formulado por Lagroye (2003b).

Como boa parte dos conceitos de ciências sociais, aquele de politização tem como origem etimológica determinados processos, situaçóes ou condiçóes concretas, no caso, principalmente a passagem de algo para a situação de ter como referência a "política". Entretanto, como ocorre nesses casos, o fato concreto que está na origem etimológica não tem qualquer importância enquanto tal e, inclusive, se for levado a sério no sentido da "aplicação de conceito", necessariamente gera redundância. Em síntese, no caso, o que pode ter alguma relevância consiste em que esta passagem para algo referido como da ordem "política” pode ter implicações relativas a fenômenos sociais envolvidos, sejam, por exemplo, estruturas sociais ou de dominação, relaçóes com 
a dimensão "política", constituição social dessa dimensão e assim por diante. Mas tudo isso ou qualquer outro aspecto envolvido somente toma sentido como objeto de estudo conforme sua inscrição em determinada perspectiva teórica e epistemológica.

Por outro lado, ainda quanto às ciências sociais relativamente ao tema da politização no Brasil ou à periferia em geral, cabe destacar a emergência de uma série de estudos extremamente relevantes em temas conexos no decorrer das últimas décadas. Em geral, são estudos realizados por pesquisadores estrangeiros e alguns sob sua orientaçáo direta. Diversamente dos estudos europeus que em boa medida têm os processos de politização na constituição do corpo eleitoral ou em problemas associados à representação política, estes estudos enfocando aspectos conexos à politização no Brasil ou na América Latina em geral estão mais diretamente centrados nas modalidades de representação de interesse e na formulação e implementação de políticas governamentais.

Sem pretensão de entrar em detalhes quanto a este tipo de trabalho, vale a pena apontar alguns casos exemplares. Nesse sentido, cronologicamente, um dos primeiros a se destacar é o trabalho de Schmitter (1971), empiricamente centrado no Governo Vargas, mas cujo interesse decorre da riqueza das demonstraçóes das particularidades e da complexidade e contradiçóes da estrutura de representação de interesses e formulação de políticas. Ainda que o foco principal esteja dirigido à complexidade da evolução da estrutura de representação de interesses, fica evidente o peso da utilização de organismos "burocráticos" (no sentido brasileiro) como meio de politização. Isso não ocorre somente pela sua função de transmissão de interesses organizados às instâncias decisórias, mas pela própria constituição de um conjunto de "fóruns" ou instâncias que abrangem atividades que no ocidente seriam atribuídas às esferas legislativas e, mais recentemente, na interpretação inclusive do próprio Schmitter na Europa do Norte, ao "neocorporativismo" (SCHMITTER; LEHMBRUCH, 1979).

Para destacar mais um estudo exemplar que explicita particularidades da politização e, mais especificamente, da conversão de aparelhos de Estado em meios para tanto, pode ser tomado o de Hirschman (1963) sobre a constituição e a evolução do conjunto de políticas contra a seca no Nordeste. Fica evidente no caso que tanto a formulação como as sucessivas revisóes dos 
esquemas dos diagnósticos e formulação de políticas, ao contrário das situações nas quais a representação política é significativa, foram as agências burocráticas do próprio Poder Executivo as principais responsáveis. E envolve, particularmente, o chamado "grupo do BNDE" e de suas relaçóes com as estruturas sociais regionais e com as instâncias decisórias.

Este tipo de enfoque, tomando os próprios aparelhos ou burocracias públicas como principais agentes de politização de determinados temas conjunturalmente tidos como importantes é ainda mais central no trabalho de Martins (1985). O próprio tema central consiste nos trajetos de agentes controladores dessas burocracias. Inclusive, uma das hipóteses defendidas é a de que, no caso, estas grandes organizações estatais agem como "partidos" políticos.

Evidentemente, além desse tipo de trabalho caracterizando as particularidades brasileiras quanto às estruturas de representação de interesses e de politização, tendo como principal meio as próprias burocracias públicas, também emergiu uma série de trabalhos calcados em concepçóes "gestionárias” de poder e de política. Embora náo caiba entrar em detalhes aqui quanto a este tipo de trabalho, basta mencionar um caso exemplar que, inclusive, pode parecer um tanto anedótico. Trata-se da tentativa de Santos (1987), com base em uma bibliografia específica de origem norte-americana, em encontrar uma "solução lógica" ou "racional" para as contradições entre as políticas governamentais dirigidas às chamadas "políticas sociais" e as econômicas. Como esta "solução" não pode ser encontrada, a conclusão principal é a de que esta contradição entre políticas teria um caráter "trágico".

Desse tipo de bibliografia sinteticamente exemplificado o que deve ser retido, além da relevância das particularidades quanto a processos de politizaçáo em condições periféricas, é o caráter efêmero ou não acumulativo e segmentado das incursões das ciências sociais em âmbito local. Certamente, o caráter vertical das relaçóes com as fontes de preocupaçóes e de esquemas analíticos e, inclusive, a multiplicidade das fontes de importação que as condições periféricas configuram, dificultam ou impossibilitam a emergência de esquemas de apropriação e usos mais horizontais de modo significativo. Portanto, por mais sugestivas que contribuiçóes como as mencionadas como exemplo possam parecer, náo chegam a se estabelecer ou a se consolidar linhas de trabalho com continuidade ou desdobramentos significativos. 
Este tipo de trabalho que póe em evidência o peso e as particularidades da "política" em condiçôes periféricas, no entanto, pode ser tomado como fonte de inspiração, mas não como algo a ser replicado ou "aplicado". Isso decorre de diferentes razóes, dentre as quais, o fato de que seus respectivos objetos de estudo não consistem especificamente em processos de politização, apesar do forte grau de associação com temas conexos. Por sua vez, no que tange ao esquema analítico proposto por Lagroye relativamente às estruturas periféricas, não há o mesmo grau de elaboração alcançado nas formulaçóes dirigidas às democracias ocidentais. Embora exegeses de seu trabalho inclusive destaquem a importância das contribuiçóes de suas proposiçóes para o estudo de sociedades "exóticas", há uma evidente simplificação do grau de complexidade deste "exotismo". Isso decorre, especialmente, da diferença básica que consiste na inexistência de uma estrutura com base na política concebida como representação e na consequente oposição entre as politics e as policies (como estudado, por exemplo, nas altas esferas das burocracias públicas francesas por Eymeri, 2003). Por outro lado, estas sociedades "exóticas" ou, na linguagem de Badie e Hermet (1993, p. 147-212), extraocidentais, comportam uma enorme amplitude de diversidade, não incluindo apenas diferentes "universos" com princípios estruturantes e dinâmicas históricas próprios, mas também as chamadas "dinâmicas órfẫs" da América Latina, onde não chegam a se constituir "universos" específicos, embora não se trate de algo próximo da dinâmica ocidental. Por outro lado, como Badie e Hermet (1993, p. 189-195) e Badie (1994) e ainda Touraine (1988), em perspectiva distinta, destacam, são estruturas sociais nas quais não somente aquilo que é entendido como "política" mas também a própria violência mantêm um peso maior na dinâmica e como recurso de posição social.

E esse tipo de situação, que na linguagem de Badie e Hermet (1993) é definida como "híbrida", comporta muitos outros complicadores. Particularmente para o estudo de processos de politização ou de temas conexos, um dos principais complicadores consiste no grau de ambivalência e de polissemia que a terminologia relativa à "política" contém. Visto que, por um lado, a "política” - ou, nas palavras de Touraine (1988), a "participação" - constitui um recurso básico da estrutura social e, por outro lado, não é a "política” como representação que constitui a matriz da terminologia e dos seus significados, tudo pode ser considerado como "político", como demonstrado por Sigal 
(1996) para o caso da Argentina. Algo semelhante ocorre com o "realismo" político brasileiro, como apresentado por Pécaut (1990). Porém, ao contrário do indicado por Badie e Hermet (1993) para as democracias ocidentais, onde a política teria condiçóes de se legitimar enquanto tal, nas condiçóes periféricas em pauta está sempre associada a alguma outra problemática e sempre pode ter mais de um sentido. Disso resulta o problema básico das condiçóes de discernimento das ambivalências e da polissemia daquilo que pode ser considerado como da ordem "política”. Nessa ambivalência e polissemia um dos polos mais evidentes é aquele da "política" concebida como realização de interesses, que tende a negar seu caráter "político" na retórica externa.

Por outro lado, no polo oposto se destacam aquelas concepçóes de "política" mais explicitamente "politicistas", com retóricas que visam a converter determinadas "questóes" de diferentes ordens em "problemas políticos", expressos enquanto tais. Evidentemente, esta oposição entre modalidades na formulação e na expressão da "política" não equivale a alguma diferença no grau de sua eficácia. Em todo caso, metodologicamente, é necessário ter em consideração estas diferentes modalidades de emergência e expressão da "política", que contrasta inclusive, com a definição de politização de Lagroye (2003b) no sentido de referência a algo da esfera da "política". Por outro lado, também é necessário discernir as diferentes modalidades de expressão e estratégias de legitimação da "política”, umas mais tácitas e implícitas com base na realização de interesses já organizados e outras como a expressão de alguma "questão" com pretensões explícitas de conversão em "política”. Este discernimento de diferentes modalidades de expressão não implica algum tipo de esquema analítico objetivista, como atribuído por Aït-Aoudia et al. (2010, p. 212) ao trabalho de Eymeri (2003). Trata-se da análise das relaçóes entre processos de objetivação social em diferentes condiçóes que podem abranger distintas dimensóes, recursos e estratégias de legitimaçáo. Evidentemente, como já mencionado, esta expressão do caráter explicitamente "político", além de emblemática, também pode adquirir um sentido negativo, constituindo objeto de denúncia.

Em termos metodológicos mais gerais, o ponto que deve ser destacado consiste na premissa segundo a qual o estudo de processos de politização não constitui algum exercício de constatação ou de aferição de que algo passou a ser considerado da ordem da política. Como já foi mencionado, não 
parece heuristicamente fértil alguma busca por especificação conceitual tendo em vista o "enquadramento" de alguma "realidade", como parece ser o caso, inclusive, de alguns comentaristas do conceito de politizaçáo. Além de uma concepção de ciências sociais que toma seu exercício como "aplicação de conceitos", o problema mais geral é o perigo de redundância que isso implica. Representa aquela perspectiva ou postura deducionista que consiste em tentar constatar empiricamente aquilo que já está implícito na formulação do próprio problema, como nos exemplos um tanto anedóticos de antigos marxistas que tentam comprovar a proletarização como resultado da expansão do capitalismo ou, então, mais recentemente, de adeptos de alguma versão do "pluralismo" buscando evidências de que a difusão e adoção de valores associados a esta moral cívica podem resultar em práticas sociais ou em opinióes em conformidade com o próprio "pluralismo". No que tange especificamente ao conceito de politização, este tipo de problema adquire características próprias, por uma série de razóes. Dentre estas, destaca-se o já mencionado fato de que, a exemplo dos demais conceitos, no estudo de processos de politização a definição conceitual somente adquire sentido em sua inscrição teórica e epistemológica. Portanto, não implica tomar determinado conceito, mas a formulação de determinado objeto cuja fundamentação decorre de alguma problemática. Além disso, tomado em si, qualquer processo de politização pode parecer banal, a não ser que sejam contemplados os problemas relativos às suas condiçóes sociais de possibilidade, seja em sua objetivação enquanto tal ou em sua legitimação como forma de dominação. $\mathrm{O}$ problema não se esgota na passagem de algo por algum processo de politização no sentido da inclusão na condição de ser referido como da ordem "política" e, portanto, tendo a dimensão "política" como referência, mas inclui suas implicaçôes sociológicas. Por outro lado, pelo menos no atual estado das ciências sociais e da diversidade de significados de "política" e das possibilidades de "politização" ou de "despolitização", não caberia qualquer tentativa apriorística de generalização ou de modelização. Ao mesmo tempo em que o conceito de politização somente tem sentido em sua inserção teórica e epistemológica, os estudos de processos concretos de politizaçáo servem mais como meio para elucidar problemas conexos do que como algo substantivo.

Foi com esta perspectiva de que a politização não pode ser tomada como algo substantivo a ser constatado, mas como problema de investigaçáo que 
deve ser considerado em seus fundamentos teóricos e epistemológicos, que foram postos em prática diferentes trabalhos de investigação empírica, seja abrangendo diretamente questôes relativas à politizaçáo ou temas conexos, às suas condiçóes de possibilidade e modalidades. Logo, muitos desses estudos têm como objeto problemas relativos a condiçóes e recursos sociais e a lógicas de ação envolvidas nisso, o que se aplica também aos trabalhos originais que estão na base das definiçóes de Lagroye (2003b) e nos exercícios de sua utilizaçáo para estudos empíricos. Por exemplo, praticamente todos os trabalhos que compóem a coletânea dedicada ao tema (LAGROYE, 2003) consistem em análises de materiais previamente utilizados para o estudo de determinadas condiçôes, visto que os aspectos relativos à politização ou ao significado da "política", em geral, constituem apenas uma das dimensões em foco. Por outro lado, no caso em pauta, por se tratar de condiçôes periféricas, além das dificuldades e dos obstáculos em geral presentes neste tipo de estudo, são acrescidos outros. Em termos gerais, alguns desses problemas mais desafiadores decorrem dos perigos de uso das ciências sociais como meio de racionalização (no sentido weberiano). Além disso, está sempre presente o desafio de evitar o raciocínio analógico, tendo em vista as condiçôes periféricas em foco e, por outro lado, o fato de que tanto o conceito de politização como o esquema analítico subjacente têm como referencial principal as sociedades ocidentais.

Em todo caso, mais que alguma síntese ou balanço geral, a seguir são apresentados apenas alguns casos exemplares deste tipo de problemas, extraídos de diferentes trabalhos, direta ou indiretamente, tendo a politização como objeto. O mais importante a destacar é que estes problemas e desafios decorrentes das condiçôes periféricas em pauta abrangem os aspectos centrais da própria conceituação e esquema analítico de Lagroye (2003b), a começar pela definição de processo de politização como algo que vai de encontro e transforma ou subverte o sentido normal da divisão de trabalho. Ocorre que, por não estar em pauta uma estrutura social burguesa, assentada na divisão profissional do trabalho, mas algo cujas categorias socialmente dominantes em boa medida são herdeiras de estruturas escravistas - isto é, a divisão social do trabalho profissional não está em sua base -, esta definição de politização adquire outro sentido. Isso pode ser constatado em um dos primeiros trabalhos sobre este tipo de tema, tomando empiricamente a formação da "elite" médica no Brasil (CORADINI, 1997). Evidentemente, isso tem fortes consequências 
metodológicas, em especial no que tange aos significados de indicadores de posição e origens sociais, sobretudo os relativos às ocupaçóes profissionais, o que, evidentemente, não abrange somente a "elite" médica, mas o conjunto das categorias socialmente dominantes.

No entanto, além desse aspecto relativo à divisão social do trabalho e da posição externa de categorias em posição social dominante, nesse tipo de trabalho outros aspectos básicos contrastam com o ocidente, particularmente no que tange ao politicismo característico. Nesse caso específico da "elite" médica, por exemplo, comparativamente à homóloga francesa, cuja tendência histórica foi de crescente distanciamento da "política" e fortalecimento da "profissão" como referência, ocorre exatamente o contrário. Sem suprimir o antigo clientelismo e clanismo formado no decorrer do período imperial, foi aumentando o peso de diferentes tipos de corporativismo, sempre mesclado ao clientelismo e com a participação direta na "política" no sentido mais amplo. Isso abrange tanto envolvimento em processos eleitorais como no spoil system e nas diferentes modalidades de corporativismo e, especialmente, na ocupação de cargos públicos por cooptação ou "indicação - para mais detalhes, ver Coradini (1997, 2005).

Como seria de esperar, para além de segmentos de "elites" com base em determinadas corporações ocupacionais, como a "elite" médica ou "elites" culturais e políticas regionais e suas respectivas concepçóes de "cultura" e de "política" (CORADINI, 2003), as principais situaçóes e oportunidades de estudos de processos de politização ou de relaçóes em geral com a "política” são constituídas pelo militantismo. Isso inclui suas diferentes condiçóes, modalidades, tipos de organização e representação de interesses, cuja amplitude aumentou com o final do período ditatorial. Estas novas condiçóes suscitam a emergência de novas e melhores condiçóes de estudo do militantismo, abrangendo, inclusive, profissionais da representação política, particularmente através do recorte de determinadas mobilizaçóes. Estas mobilizaçóes incluem em especial movimentos como o Fórum Social Mundial (CORADINI, 2008b), o Orçamento Participativo e seus contrapontos (CORADINI, 2012b), o Movimento dos Trabalhadores Rurais Sem Terra (CORADINI, 2011b), entre outros.

Em uma visão retrospectiva, por um lado, estas condiçóes estudadas possibilitam a constatação de uma grande variedade de meios ou recursos de ação, 
de interesses, de tipos de retribuiçôes, de concepções de "política" e, portanto, de lógicas de ação envolvidas. Por exemplo, ficam evidentes e facilmente discerníveis concepçôes de "política" enquanto meio de e capacidade de gestão ou de "administração", como criação de oportunidades de "participação", como organização e encaminhamento de "soluçôes" para problemas tendo como base o pertencimento prévio em organizaçôes e sua redefinição, como busca de "justiça" ou de "direitos" previamente já enunciados em outras instâncias, dentre tantos outros princípios de definiçáo em confronto ou, então, em amálgama. Particularmente no que tange ao MST, certamente por se tratar de condiçôes sociais que podem ser consideradas como extremas e as diferenças de recursos e de perspectivas que englobam, foi possível, inclusive, a apreensão de princípios e demandas por retribuição ao militantismo subjacentes menos perceptíveis em outras circunstâncias. Nesse caso, sem excluir o peso de outros elementos não utilitaristas, particularmente para os militantes mais próximos do controle da organização e de sua ideologia, como destacado por Gaxie (2005), outro aspecto que fica evidente. Trata-se da natureza específica das retribuiçôes esperadas pelos controladores e ideólogos da organização, que não consiste apenas em não ser redutíveis a algo utilitarista, mas particularmente por seu caráter com base no capital cultural. Ou seja, mais que o controle e a ideologia da organização, um primeiro tipo de retribuição que entra em pauta nas expectativas de retribuição tem como base não apenas algo não necessariamente utilitário, mas cuja definição depende diretamente do capital cultural e, portanto, constituído como bem simbólico, como o reconhecimento enquanto "liderança" e a capacidade de formulação de "projetos" tidos como socialmente relevantes e assim por diante. No extremo oposto, mais próximas das expectativas e das demandas da "base" se destacam as retribuiçôes de cunho mais utilitário, no caso, evidentemente, a obtenção de alguma área de terra e, por isso, mais diretamente associadas às condiçóes materiais de reprodução da condição social - para mais detalhes, Coradini (2011b).

Por outro lado, apesar das possibilidades de estudo do militantismo ou da politização em geral em condiçôes politicistas, os resultados podem adquirir um caráter um tanto paradoxal. Ocorre que, seja devido ao "realismo" do pensamento "sociológico" brasileiro descrito por Pécaut (1990), seja em razão do politicismo que tende a incorporar e retraduzir crescentemente o moralismo subjacente aos esquemas associados ao "pluralismo" norte-americano, os 
esforços em tomar este substancialismo como objeto de estudo pelas ciências sociais pode ser visto como algo estranho ou uma espécie de nonsense. Uma vez que o politicismo - associado ou não com determinada moral cívica subjacente ao "pluralismo" - é naturalizado, sua transformação em objeto de estudo tende a se restringir às condiçôes de sua eficácia, com a exclusão apriorística de suas razôes de ser e das lógicas de ação envolvidas. Por conseguinte, as chances de legitimação desse tipo de estudo são muito limitadas e com grande potencial de geração de mal entendidos.

Algo semelhante se aplica aos estudos de politização tomando mais diretamente como recorte empírico especialistas ou profissionais da política formalmente definidos como tal, ou seja, a representação política com base em processos eleitorais e suas vinculaçóes com as estruturas de representação de interesses. Nesse caso também, contrariamente àquilo que seria algo negativo em uma ótica substancialista e funcionalista, a quantidade de problemas em aberto e desafios analíticos não contornados constitui um dos principais incentivos. Isso se aplica a diferentes unidades de análise que constituem estudos empíricos, entre os quais, particularmente: o trabalho tomando as bases sociais, associativas e partidárias do conjunto de candidatos de uma eleição em âmbito estadual (Rio Grande do Sul), tendo em vista em especial o exame dos princípios constitutivos daquilo que seria politica ou, pelo menos, eleitoralmente "representado" como "política" (CORADINI, 2001). Portanto, é essencial discernir e explicitar a constituição social e as dinâmicas e lógicas de ação na conversão de interesses e valores sociais naquilo que, nas condiçóes de determinada conjuntura específica, seria politizável.

Além do esperado e evidente forte grau de correlação entre os indicadores de posição social disponíveis e, particularmente, as modalidades de ingresso e trajetos nas vinculaçôes partidárias com as respectivas posiçôes e concepções de política, um dos aspectos que se ressalta nesse tipo de trabalho são os vínculos com interesses previamente organizados de diferentes tipos. Portanto, se por um lado os processos eleitorais e de constituição da representação política evidentemente, para sua própria existência e modalidades conforme as respectivas condiçóes concretas, dependem diretamente da disponibilidade mínima de sua estruturação; por outro, aquilo que é politizável no espaço das disputas eleitorais já está socialmente constituído como definição, organização e representação de interesses. 
Essa é a típica linha de trabalho que em condições periféricas e na ausência de alguma estrutura que envolvesse algo mais que esforços individuais (diversamente dos trabalhos vinculados àqueles de Lagroye) tende a resultar mais em questôes em aberto que em continuidade. Em todo caso, mesmo nessas condiçôes individuais isoladas, algumas das questóes em aberto foram retomadas, dentre as quais, particularmente as associadas às relaçóes entre representação política e interesses organizados (CORADINI, 2006, 2011). Mais ainda que em outras linhas de trabalho, nesse caso, conjuntamente com alguns resultados que parecem muito instigantes, os desafios e as questôes indefinidamente em aberto são mais agudos. A primeira dessas linhas de trabalho que consiste em desdobramento daquela supracitada está centrada especificamente nas relações entre representação política e organização de interesses. Tomando os trajetos dos deputados federais, senadores e ministros de alguns governos, além dos indicadores de posição social pertinentes com informações disponíveis, foi possível examinar as relaçóes com as diferentes modalidades e os tipos de organização de interesse (sindicatos, associações patronais, de profissionais, organizaçóes filantrópicas, religiosas, étnicas etc.). A principal constatação é a crescente intensificação desse tipo de vínculo na medida em que se aproxima o período mais recente, abrangendo a maior parte dos indivíduos examinados; contudo, para o que está em pauta, mais que a intensificação do peso de interesses organizados nas chances de obtenção de algum cargo de representação política, interessa destacar a complexidade das modalidades, recursos e significados dos processos de politização.

As relaçóes entre interesses organizados ou engajamento associativo e representação política são diversas inclusive ao se comparar países ocidentais, podendo haver situaçóes de independência quase absoluta, com princípios de legitimação próprios, até determinado grau de dependência, particularmente no que se refere a determinadas categorias sociais e posiçóes político-ideológicas. No entanto, no caso em pauta, o mais instigante consiste no amálgama de modalidades e recursos interdependentes e em confronto, tanto na representação de interesses como nos processos político-eleitorais. Evidentemente, nessas condiçóes qualquer tipo de engajamento em alguma organização tende a adquirir um sentido de "política", mas com forte grau de polissemia, particularmente como decorrência da ambivalência generalizada frente aos significados desta "política". Quanto às modalidades e aos recursos de representação 
de interesses e representação política em pauta, está incluída a grande variedade de organizaçôes de cunho corporativo (na linguagem nativa, "classista") e sindical (patronal, de autônomos e de empregados), "culturais", de cunho religioso, filantrópico ou assistencial, e assim por diante. Isso tudo não interage apenas com os processos de representação político-eleitoral, mas também - e de modo muito direto - com o spoil system brasileiro, particularmente através dos chamados cargos de "confiança" ou por "indicação", que equivalem à grande maioria dos postos com poder de decisão política no Brasil, cujas bases dependem tanto do engajamento em grupos de interesse como de lealdades partidárias, em combinaçóes e condições as mais diversas. A isso se acresce o "lobbismo" em deferentes modalidades e graus de legitimidade e de visibilidade. Por exemplo, basta qualquer exame mais cuidadoso das informaçóes divulgadas na imprensa para constatar o reconhecimento mais explícito ou cifrado relativo de manifestaçôes de organizaçóes que à primeira vista estariam excluídas da "política", seja de interesses econômicos, corporativos, ideológicos, dentre tantas outros.

O mais importante a destacar para o que está em pauta é a constatação de que, além do altíssimo grau de correspondência entre a estrutura de posiçóes e a segmentaçáo sociais e aquela da representação política, a própria multidimensionalidade e, particularmente, sua expressão nas organizaçóes de interesse, é homóloga a esta representação político-partidária. Disso resulta o espaço de representação política ser não apenas mais heterônomo ou poroso relativamente aos interesses organizados, mas mais multifacetado e, consequentemente, com posiçóes mais ambivalentes. Como já destacado nas ciências sociais, o espaço ou "campo" de representação política, por envolver a especialização e divisão entre mandantes e mandatários, tende a manter dois tipos de retórica, um de caráter "exotérico" e outro "esotérico" (BOURDIEU, 1981, p. 8-9). Ocorre que, nas condiçôes em pauta, não está presente apenas esta divisão de retórica conforme a categoria dos destinatários das mensagens, mas uma multiplicidade de "públicos" ou de instâncias que constituem diferenciadamente o conjunto contraditório daquilo que pode ser "representado" politicamente. Na base disso, além da multiplicidade contraditória dos interesses em disputa pelo reconhecimento e representaçáo política em diferentes modalidades e com recursos e meios de ação relativamente próprios, a condição de representante político está sempre diretamente associada àquela de mediador. 
No que tange especificamente ao estudo da politização, a principal consequência dessas condiçôes sinteticamente apontadas consiste na diversidade de significados que as referências à "política” podem adquirir. Daí a importância das indicaçóes de trabalhos como o de Eymeri (2003), particularmente quanto às relaçôes entre as dimensôes explicitamente objetivadas e aquelas implícitas. Como sugerido por Gaxie et al. (1990), nas disputas parlamentares na França ocorre a oposição entre as tomadas de posição cuja lógica de ação está mais diretamente centrada nas decisóes de políticas governamentais e aquelas mais diretamente dirigidas ao público "externo", tendo em vista a legitimação da respectiva posição política. No caso do Brasil, no entanto, as diferenças quanto às referências à "política” obedecem também a outras condiçôes e lógicas de ação. Nesse ponto, o aspecto mais geral a destacar é a bipolaridade na qual, de um lado, se encontram aquelas situaçóes de agentes fortemente vinculados a interesses organizados e com muito poder de influência ou de decisão, como ministros da área econômica, cuja expressão em termos de "política" é mais implícita ou restrita e publicamente quase ausente. Como indicado, este é o caso de muitos ministros que, além da maior ausência de tomadas de posição explicitamente político-partidária, geralmente não formalizam qualquer filiação partidária formal. Mas este também é o caso de deputados e senadores que, apesar da obrigatoriedade formal de filiação partidária para participar de disputas eleitorais, mantêm determinadas posturas com pretensóes de maior distanciamento da "política" partidária e, particularmente, daquilo que é considerado como sua versão mais "ideológica”. Em síntese, o maior envolvimento e a posse de recursos políticos, enquanto representação de interesses e poder de decisáo, podem equivaler a uma perspectiva de um aparente distanciamento estratégico da "política", o que equivale a um relacionamento mais estrito com uma das suas versóes em confronto, visto que, apesar do politicismo ambiente, isso não resulta na legitimação da "política" enquanto tal, como apontado por Badie e Hermet (1993, p. 108) para o ocidente. No polo oposto, destacam-se aquelas posturas explicitamente em nome da "política” não apenas em termos de engajamento e militantismo como também na retórica e nas tomadas de posição. Em geral, envolve representantes de categorias sociais e ideológicas específicas, como as chamadas "minorias". Todavia, o que importa é destacar que a importância da "política" nesse caso em termos de militantismo e retórica não equivale à capacidade de poder de influência 
ou de decisão, ao contrário do polo oposto. Há, ainda, os representantes de categorias social e politicamente mais dominadas com posturas distantes da retórica política, como aqueles vinculados a determinadas igrejas ou religióes. Porém, nesse caso, mais que algum antipoliticismo, ocorre uma modalidade e versão específicas da conversão da posição de mediação em politização. Uma das implicações disso é a tendência ao aumento da distância social e política entre os representantes e os representados, apesar da identificaçáo religiosa ou ideológica em geral.

Isso também tem desdobramentos quanto a linhas de trabalho empírico, particularmente relacionados à conversão da ocupação de cargos políticos "por indicação" e, portanto, não obtidos formalmente por disputas eleitorais, que, em geral, são vistos inclusive pelas ciências sociais como "técnicos" e não "políticos", em recursos eleitorais. O peso do setor público no recrutamento de "elites" políticas, seja através de disputas eleitorais (DOGAN, 1999) ou de modo mais associado às burocracias públicas (BIRNBAUM, 1994) já foi destacado para países como a França ou no recrutamento das elites parlamentares no conjunto da Europa (BEST; COTTA 2000; COTTA; ALMEIDA, 2004), sendo analisado de diferentes perspectivas. $\mathrm{O}$ que parece mais importante no caso em pauta é a forte associação entre ocupação de cargos públicos por cooptação e não por vias eleitorais, contudo, de modo interdependente com as disputas eleitorais, inclusive, por estarem inscritos no spoil system brasileiro e sua integração na estrutura de mediação. É nesse sentido que se abrem diferentes perspectivas analíticas para o estudo de processos "não clássicos" de politização, visto que em um dos trabalhos empíricos realizados (CORADINI, 2012) a principal hipótese perseguida é a de que estas condiçóes favorecem a formação de carisma da função e, portanto, a conversão de cargos com aparência "técnica" em recursos eleitorais e vice-versa.

Em síntese, nesta multiplicidade de modalidades e condiçóes de politização, se destaca um polo mais diretamente centrado em interesses organizados cuja legitimação depende menos diretamente da proclamação pública de seu caráter "político" e, no polo oposto, se situa a miríade de empresas de mobilização as mais variadas, inclusive aquelas associadas a empresas morais, frequentemente configurando algo próximo de vanguardas culturais. Por outro lado, além da forte associação dos recursos de posição social daquilo que é 
atribuído à "política" - ou, nas palavras de Touraine (1988), da "participação" -, do neopatrimonialismo e dos interesses organizados, o principal meio de realização de interesses por meio da politização consiste no spoil system multifacetado que está na base da "participação", além daquelas modalidades publicamente menos legítimas, como as diferentes modalidades de clientelismo. Como é sabido, muitos dos países nessas condiçôes periféricas, entre os quais está o Brasil, contam com eleiçôes cuja frequência e regularidade são cíclicas. Porém, para o que está em pauta, o mais importante a destacar é que não apenas se trata de algo completamente distinto comparativamente aos países ocidentais, como o principal problema analítico para as ciências sociais consiste nos possíveis significados das eleiçôes, sob pena de se cair em raciocínio analógico e deduzir com base nas interpretaçóes do ocidente. Para desgosto dos que tomam a moral cívica que pressupóe as organizaçôes partidárias como o meio por excelência de politização, seja em alguma versão do "pluralismo" ou de outra filosofia política qualquer, evidentemente, nesse tipo de estrutura o peso e, particularmente, as condiçóes de existência e dinâmica desse tipo de organização adquire contornos próprios. Para o que está em pauta, o importante a reter é que estas perspectivas centradas em alguma moral cívica que, por uma transposição analógica do ocidente, tem nas organizaçóes partidárias o meio por excelência da politização, sua fraqueza ou desorganização tende a ser tomadas no sentido da despolitizaçáo. Além de indicadores como a alta rotatividade na filiação partidária por parte dos profissionais da política, algumas outras indicaçóes geralmente são tomadas como evidência dessa baixa politizaçáo e um dos casos exemplares mais frequentemente utilizados para tanto é a quantidade e a importância das chamadas frentes parlamentares.

Ocorre que com o grau de interdependência entre a estrutura de representação política e a de mediação e representação de interesses, ao mesmo tempo em que há um maior peso e importância daquilo que é atribuído à "política" na hierarquização social, as modalidades e os recursos de politização em pauta têm menor afinidade com o engajamento e a afiliação partidárias. No entanto, nessas condiçôes, mecanismos tidos como índices e evidências de despolitização, como as frentes parlamentares, podem representar exatamente o contrário, ou seja, a politização de interesses os mais diversos, como demonstrado empiricamente em um trabalho específico (CORADINI, 2008).

Em todo caso, para o que está em pauta cabe reter que, apesar da lamentada fraca importância das organizaçôes partidárias na constituição social da 
política, há uma série de princípios que regem a hierarquização e a confluência de interesses pela ocupação de cargos e a disputa por recursos públicos, a começar pelas relaçóes centro/periferia, que se manifestam, inclusive, na hierarquização dos próprios cargos públicos. Porém, no âmbito dos profissionais da política há um conjunto de outros recursos e princípios de hierarquização e de divisão, que se manifestam diretamente, inclusive, nas mencionadas frentes parlamentares. Em termos sintéticos, o mais importante a destacar é que estas frentes parlamentares, ao contrário das interpretaçôes com base na moral cívica vigente, não são constituídas ou promovidas pelos agentes políticos menos "politizados" ou na linguagem do meio, pelo chamado "baixo clero". Além disso, para além da pequena importância atribuída aos partidos como referência de tomadas de posição e alianças de interesses, ocorre um domínio geral muito claro dos eixos de clivagens e oposiçôes, bem como dos interesses e empresas morais em confronto, inclusive, nas e entre as frentes parlamentares de determinada conjuntura.

Disso resulta que este tipo de estrutura, com menos peso de organizaçóes partidárias, mas com maior importância da organização e defesa de interesses Em uma estrutura de mediação calcada em lealdades em cascata aumenta o grau de ambivalência e a multiplicidade de alvos da retórica de legitimaçáo. Outra consequência direta disso é o maior distanciamento social, político e ideológico que pode ocorrer entre representantes políticos ou de interesses e suas bases eleitorais, visto que os princípios e as lógicas de ação presentes nos processos eleitorais são relativamente independentes daqueles das "articulaçôes" e "negociaçôes" entre os profissionais da política. Em todo caso, embora de modo heterônomo e diferenciado conforme cada tipo de "participante" e do grau de ambivalência contido, os resultados dependem do sucesso de algum processo de politização, evidentemente, com significados e sentidos diferenciados.

\section{Considerações finais}

Como já mencionado no início deste texto, apontam-se algumas implicaçôes no estudo da politização, particularmente nas formulaçôes de Lagroye e suas possibilidades e limites em condiçóes periféricas, como aquelas em pauta. Simultaneamente, são feitas algumas indicaçôes tomando as próprias experiências nesse tipo de estudo, ou de temas conexos. 
Essas implicações na utilização de formulações relativas à politização nas condições periféricas abrangem tanto condições e problemas teóricos e epistemológicos como as particularidades sócio-históricas. No que tange às implicaçóes e requerimentos teóricos e epistemológicos, entra em pauta uma série de precondiçôes, evidentemente, de difícil superação nas condiçóes periféricas, o que não exclui, inclusive, parte das ciências sociais nos centros ocidentais. Uma das primeiras dessas precondiçōes que deve ser destacada pelas suas implicaçóes diretas é o problema da autonomia das ciências sociais. No caso, particularmente na perspectiva de Lagroye (2003), suas próprias razóes de ser não fazem sentido sem esta autonomia relativa. Por exemplo, tanto suas definiçóes de processos de politização como de conceitos correlatos estão fundamentados Em uma concepção de poder com base na sociologia da dominação weberiana, visto que o poder político remete à dimensão dos conflitos "sem solução". A exemplo das demais definiçôes, isso tem uma série de implicações teóricas e metodológicas.

Nos centros ocidentais, vêm aumentando as discussóes epistemológicas que póem em questão as próprias possibilidades de existência das ciências sociais. Além dos problemas teóricos e metodológicos, as dificuldades principais decorrem da sua falta de autonomia, além de outros problemas metodológicos. Em geral, o que ocorre com a chamada ciência política serve como exemplo extremo desta falta de autonomia - ver especialmente Hammersley (2014).

Ocorre que, nas condiçóes periféricas em pauta, para além do que é considerado como ciência política, portanto, para o conjunto das ciências sociais, normalmente este tipo de problema nem chega a entrar em pauta de modo significativo e sério. Porém, mais que algum purismo teórico ou metodológico, entra em questão o próprio conjunto de problemas analíticos e hipóteses subjacentes aos processos de politização propostos por Lagroye. Uma das implicaçóes mais gerais dessas condições associadas às condiçóes periféricas é que a adoção de alguma concepção de poder calcada na moral cívica, geralmente associada ao chamado "pluralismo", é inevitável. Ou seja, o exercício do poder político e, evidentemente, inclusive os processos de politização passam a ser definidos e tomados no sentido da "solução de problemas". Esta concepção "gestionária" e moralista da dominação política, além de convergente com a utilização das ciências sociais como meio de "racionalização" (no sentido 
weberiano), tem o efeito de hibridação do moralismo importado das filosofias subjacentes ao "pluralismo" norte-americano com o politicismo vigente na periferia em pauta.

No que tange às particularidades das condições periféricas, além do maior peso daquilo que é atribuído à "política" na estruturação social, como destacado pela bibliografia pertinente, outros problemas tornam os processos de politização particularmente complexos. Um desses problemas decorre das origens do referencial que respalda as definiçóes conceituais de politização, tendo como referência principal as chamadas democracias ocidentais. Disso resulta que, se por um lado nessas condiçôes centrais, no âmbito das práticas sociais e da linguagem comum a "política" é concebida como "representação", em oposição às demais dimensóes, nas condiçóes periféricas em pauta os princípios de definição em confronto são diversos e múltiplos. Consequentemente, se, por um lado, a "política" tem um peso maior na definição das posiçóes sociais; por outro, não ocorre apenas uma forte polissemia quanto a seus possíveis significados mas também relativamente às situaçóes e práticas sociais envolvidas. Ou seja, não ocorre apenas um maior grau de heteronomia, mas a existência de múltiplas esferas ou circuitos com princípios de seleção distintos que circunscrevem algo que pode ser tido como da ordem "política".

Além das dificuldades técnicas para o acesso ao exame dessa multiplicidade de circuitos, situaçóes ou esferas que podem ser incluídos de alguma forma como de ordem "política", outro dos principais problemas metodológicos que decorre disso consiste no discernimento de alguns princípios gerais dessas definiçôes ou critérios de inclusão de "política". Como indicado com base em estudos empíricos em um polo se destacam perspectivas que tendem a associar à "política" condiçôes e possibilidades de influência ou de determinação de decisôes governamentais. Em geral, destas perspectivas são menos importantes e até insignificantes as estratégias de politização com base na proclamação ou investimentos na legitimação pública mais ampla de tomadas de posição. No polo oposto, destacam-se aquelas perspectivas cujo significado principal consiste na legitimaçáo de determinados interesses como "causas" a ser defendidas, frequentemente associadas a categorias sociais vinculadas a organizaçóes de cunho mais "cultural" ou ideológico, publicamente proclamados em nome de regras e valores morais. Tanto no primeiro como no segundo caso, em geral, se trata de redefinições de antigas questôes já associadas a políticas 
governamentais e, inclusive, com origem em grandes burocracias internacionais, em fase de redefiniçóes.

\section{Referências}

AÏT-AOUDIA, M. et al. Contribution à une histoire sociale de la conception lagroyenne de la politisation. Critique Internationale, n. 48, p. 207-220, 2010.

. et al. Indicateurs et vecteurs de la politisation des individus: les vertus heuristiques du croisement des regards. Critique internationale, n. 50, p. 9-20, 2011.

ALMOND, G. A. A comparative study of interest groups and the political process. The American Political Science Review, v. LII, n. 1, p. 270-282, 1958.

. Separate tables: schools and sects in political science. Political Science and Politics, v. 21 , n. 4 , p. $828-842,1988$ b.

The return of the State. American Political Science Review, v. 82, n. 3, p. 853-874, sept. 1988.

A Discipline Divided: Schools and Sects in Political Science. London: Sage Publications, 1990.

BADIE, B. Le modèle centre-péripherie. In: Le Développment Politique. Paris: Economica, 1994. p. 111-133.

.; HERMET, G. Política Comparada. México: Fondo de Cultura Económica, 1993.

BEST, H.; COTTA, M. (Ed.). Parlamentary Representatives in Europe 1848-2000: Legislative Recruitment and Careers in Eleven European Countries. Oxford: Oxford University Press, 2000.

BIRnBAUM, P. Les Sommets de l'État: Essai sur l'élite du pouvoir em France. Paris: Éditions du Seuil, 1994.

BOURDIEU, P. La représentation politique. Actes de la Recherche en Sciences Sociales, v. 36-37, p. 3-24, fév./mars 1981.

BRAUD, P. De pouvoir en général au pouvoir politique. In: GRAWITZ, M.; LECA, J. (Dir.). Traité de Science Politique; La Science Politique, Science Sociale; L'Ordre Politique. Paris: Presses Universitaire de France, 1985. v. 1. p. 335-393.

CORADINI, O. L. Ambivalências na representação de classe e a noção de "trabalhador rural". In: NAVARrO, Z. (Org.). Política, Protesto e Cidadania no Campo. Porto Alegre: Editora da Universidade/UFRGS, 1996. p. 171-188. 
. Grandes famílias e elite "profissional" na medicina no Brasil. História, Ciências, Saúde - Manguinhos, v. 3, n. 3, p. 425-466, 1997.

Em Nome de Quem? Recursos Sociais no Recrutamento de Elites Políticas. Rio de Janeiro: Relume Dumará, 2001.

Escolarização, militantismo e mecanismos de "participação" política. In:

Como se Fazem Eleiçóes no Brasil. Rio de Janeiro: Relume Dumaré, 2002. p. 103-153.

As missôes da "cultura" e da "política": confrontos e reconversôes de elites culturais e políticas no Rio Grande do Sul (1920-1960). Estudos Históricos, n. 32, p. 125-144, 2003.

Representação profissional e elites políticas no Brasil no período recente. Política $\mathbf{8}$ Sociedade - Revista de Sociologia Política, v. 5, n. 9, p. 123-161, out. 2006.

Les participants et les organizateurs du Forum Social Mondial: la diversité du militantisme. Cultures \& Conflits, n. 70, p. 153-175, 2008 b.

. Politização de interesses através de frentes parlamentares. Tomo, ano X, n. 13, p. 75-92, jul./dez. 2008.

- Recursos de origem, investimentos e expectativas de retribuição na militância no MST. Espacio Abierto - Cuaderno Venezolano de Sociología, v. 19, n. 3, p. 445-473, jul./ sept. 2010.

Representação política e de interesses: bases associativas dos deputados federais de 1999-2007. Sociedade e Estado, v. 26, n. 1, p. 197-220, jan./abr. 2011.

Resources of origin, investments and expectations of rewards in the militancy of the Landless Rural Workers Movement (MST). International Review of Sociology, v. 21, n. 1, p. 67-87, march 2011b.

. Conselhos regionais de desenvolvimento, orçamento participativo e confrontos entre concepçôes de "participação" - o caso do Rio Grande do Sul. In: HEREDIA, M. B. A. de; PAlmeIrA, M. (Org.). Política, Governo e Participaçáo Popular: Conselhos, orçamento participativo e outras experiências. Rio de Janeiro: 7 Letras, 2012b. p. 65-110.

. Cargos e funçóes públicas e candidaturas eleitorais. Sociedade e Estado, v. 27, n. 3, p. 689-708, set./dez. 2012.

COTTA, M.; ALMEIDA, P. T. de. De serviteurs de l'État à représentants élus: les parlementaires originaires du secteur public en Europe. Pôle Sur, n. 21, p. 101-122, 2004. 
DESROSIÈRES, A. Gouverner Par les Nombres: L'Argument Statistique II. Paris: Presses de l'École des Mines, 2008.

DEZALAY, Y.; GARTH, B. G. The Internationalisation of Palace Wars: Lawyers, Economist and the Contest to Transform Latin America States. Chicago: University of Chicago Press, 2002.

DOGAN, M. Les professions propices à la carrière politique. Osmose, filières e viviers. In: OFFERlÉ, M. (Ed.). La Profession politique: XIXe-XXe siècles. Paris: Belin, 1999. p. 135-169.

DUCHESNE, S.; HAEGEL, F. La politisation des discussions, au croisement des logiques de spécialisation et de conflictualisation. Revue française de science politique, v. 54, p. 877 909, 2004.

EYMERI, J. M. Frontières ou marches? De la contribuition de la haute administration à la production du politique. In: LAGROYE, J. (Dir.). La Politisation. Paris: Belin, 2003. p. $47-77$.

GARRIGOU, A. Le vote et la vertu: Comment les Français sont devenus électeurs. Paris: Presses de Science Po., 1992.

GAXIE, D. et al. (Ed.). Le "Social” Transfiguré. Sur la répresentation politique des préoccupaions “sociales”. Paris: Presses Universitaires de France, 1990.

Le cens caché. 3. ed. Paris: Seuil, 1978.

Rétributions du militantisme et paradoxes de l'action collective, Swiss 1. Political Science Review, vol. 11, p. 157-188, mar. 2005.

HAMIDI, C. Éléments pour une approche interactionniste de la politisation. Engagement associatif et rapport au politique dans des associations locales issues de l'immigration. Revue Française de Science Politique, v. 56, p. 5-25, 2006.

HAMMERSLEY, M. The Limits of Social Sciences: Causal Explanation and Value Relevance. London: Sage Publications Ltd, 2014.

HIRSCHMAN, A. O. Journeys toward Progress: Studies of Economic Policy-Making in Latin America. New York: The Twentieth Century Found, 1963.

JOBERT, B.; MUlLER, P. L'État en Action: Politiques Publiques et Corporatismes. Paris: Presses Universitaires de France, 1987. 
LACROIX, B. Ordre politique et ordre social; Objetivisme, objetivation et analyse politique. In: GRAWITZ, M.; LECA, J. (Dir.). Traité de Science Politique; La Science Politique, Science Sociale; L'Ordre Politique. Paris: Presses Universitaire de France, 1985. v. 1. p. 469-565.

LAGROYE, J. La légitimation. In: GRAWITZ, M.; LECA, J. (Dir.). Traité de Science Politique; La Science Politique, Science Sociale; L'Ordre Politique. Paris: Presses Universitaire de France, 1985. v. 1. p. 395-467.

Sociologie Politique. Paris: Preses des la Fondation Nationale des Sciences Politiques, 1991.

FRANÇOIS, B.; SAWICKI, F. Sociologie Politique. 4e. édition revue et mise à jour. Paris: Presses de Science Po et Dalloz, 2002.

. (Ed.). La Politisation. Paris: Belin, 2003a.

. Le processus de politisation. In: . (Ed.). La Politisation. Paris: Belin, 2003b. p. 359-372.

.; OFFERLÉ, M. (Dir.). Sociologie de l'Institution. Paris: Belin, 2010.

LASCOUMES, P. Les compromis parlementaires, combinaisons de surpolitisation et de souspolitisation. L'adoption des lois de réforme du Code pénal (décembre 1992) et de création du Pacs (novembre 1999). Revue Française de Science Politique, v. 59, p. 455-478, 2009.

LOWI, T. J. The return of the State: critiques. American Political Science Review, v. 82, n. 3, 875-891, sept. 1988 .

The State in Political Science: How We Become What We Study. The American Political Science Review, v. 86, n. 1, p.1-7, mar. 1992.

MARTINS, L. Estado Capitalista e Burocracia no Brasil Pós 64. Rio de Janeiro: Editora Paz e Terra, 1985.

OFFERLÉ, M. Capacités politiques et politisations: faire voter et voter, $\mathrm{xix}^{\mathrm{e}}-\mathrm{xx}^{\mathrm{e}}$ siècles (1). Genèses, n. 67, p. 131-149, 2007.

PÉCAUT, D. Os Intelectuais e a Política no Brasil: Entre o Povo e a Nação. Rio de Janeiro: Editora Ática, 1990.

SAINT MARTIN, M. de. A propos d'une rencontre entre chercheurs; Sciences sociales et politique au Brésil. Actes de la Recherche en Sciences Sociales, v. 71, n. 1, p. 129-134, 1988. 
SANTOS, W. dos. A trágica condição da política social. In: ABRANCHES, S.; SANTOS, W. dos; COIMBRA, M. (Org.). Política Social e Combate à pobreza. Rio de Janeiro: Jorge Zahar Ed., 1987. p. 33-63.

SCHMITTER, P. C. Interest conflict and political change in Brazil. Stanford: Stanford University Press, 1971.

.; LEHMBRUCH, G. (Ed.). Trends toward Corporatist Intermediation. London: Sage, 1979.

SIGAL, S. Le Rôle des intellectuels en amérique latine: la dérive des intellectuels en Argentine. Paris: Harmattan, 1996.

TALPIN, J. Ces moments qui façonnent les hommes. Éléments pour une approche pragmatiste de la compétence civique. Revue Française de Science politique, v. 60, p. 91-115, 2010.

TOURAINE, A. Palavra e Sangue: Política e Sociedade na América Latina. Campinas: Editora da UNICAMP, 1988.

WACQUANT, L. J. D.; CALHOUN, C. J. Intérêt, rationalité et culture; A propos d'un récent débat sur la théorie de l'action. Actes de la Recherche em Sciences Sociales, v. 78, p. 41-60, 1989.

WEBER, M. Economia y Sociedad: Esbozo de Sociología Comprensiva. México: Fondo de Cultura Económica, 1984.

\section{Politicization in politicians conditions: some analytical problems and results of work}

\section{Abstract}

This paper examines some implications of the study of politicization, with an emphasis on the possibilities and limits of peripheral conditions. For this, the first part of the text presents some general elements related to the definitions proposed by Jacques Lagroye, especially emphasizing the theoretical bases and the underlying epistemological problems. The second part of the exposition uses results from investigations conducted in the last decades in different empirical universes in Brazil that directly or indirectly cover issues related to politicization or related issues. From these, problems arising from the difficulties caused by the lack of autonomy of the Social Sciences and, on the other hand, from the challenges related to socio-historical particularities are 
revealed. Since, in these contexts, "politics" is given greater weight in social structuring, as well as its principles of definition are diverse and multiple, besides there are multiple circuits, with distinct principles of selection, that circumscribe something that can be considered as of the "political" order.

Keywords: Politicization. Lagroye. Periphery. Social Sciences.

Recebido em: 01.06.2017

Aprovado em: 30.08.2017 